Terr. Atmos. Ocean. Sci., Vol. 17, No. 4, 659-677, December 2006

\title{
Intraslope Basin, Seismic Facies and Sedimentary Processes in the Kaoping Slope, Offshore Southwestern Taiwan
}

\author{
Ho-Shing $\mathrm{Yu}^{1}{ }^{, *}$ and Zehn-Yin Huang ${ }^{1}$
}

(Manuscript received 28 October 2005, in final form 17 August 2006)

\begin{abstract}
Occurrence of intraslope basins and distinct seismic faices assemblages of the basin fills in the Kaoping Slope, offshore SW Taiwan, reflect interactions between regional convergent tectonics, local mud diapirism and sedimentary processes of fill-and-spill during slope development. Located west of the Kaoping Submarine Canyon, three major intraslope basins separated by diapiric mud ridges mainly trending NNE-SSW are determined. They are elongated depressions with a length ranging from 10 to $40 \mathrm{~km}$ and a width of about $12 \mathrm{~km}$, similar to intraslope basins east of the Kaoping Canyon. Basin fills are characterized by a distinct upward change in seismic facies beginning with a basal convergent-baselapping facies, succeeded by chaotic facies and overlain by parallel and draping facies. The basal convergent-baselapping facies is the most common and the parallel and draping facies is restricted to slope areas shallower than $1000 \mathrm{~m}$ in water depth. Sediments from the prograding shelf and upper slope are transported and deposited mainly in the confined basal accommodation space of intraslope basins, forming convergent-baselapping seismic facies in the early stage of the basin fill history. Rates of deposition being slower than rates of basin subsidence due to local mud diapirism kept the early intraslope basins partially filled by sediment, representing a confined style of deposition. In the late stage of basin development sediments have been transported to a lower slope distal to the sediment sources, progressively filling and spilling intraslope basins in a generally southwestward direction.
\end{abstract}

(Key words: Intraslope basin, Seismic facies, Sedimentation, Offshore, Taiwan)

\footnotetext{
${ }^{1}$ Institute of Oceanography, National Taiwan University, Taipei, Taiwan, ROC

* Corresponding author address: Prof. Ho-Shing Yu, Institute of Oceanography, National Taiwan University, Taipei, Taiwan, ROC; E-mail: yuhs@ntu.edu.tw
} 


\section{INTRODUCTION}

The stratigraphic framework and structural styles of the shelf and slope region offshore SW Taiwan, have been considerably investigated during the last five years and motivated mainly by recognition of the potential of large amounts of gas hydrate in the Kaoping Slope offshore SW Taiwan (Chi et al. 1998; Liu et al. 2006). Research indicated that the area has the most up-to-date occurrence of gas hydrates off the coast of SW Taiwan. Subsequently, the Central Geological Survey of Taiwan initiated a four-year (2004 - 2007) multi-disciplinary project to evaluate the potential of hydrate occurrence in the offshore region of SW Taiwan. This paper is a part of larger geological and geophysical investigations aiming at a full assessment of the potential of gas hydrates as a possible future energy source. The purpose of this paper is to investigate relationship between intraslope basin, seismic facies and sedimentary processes. The results of this study are then incorporated within larger geological and geophysical frameworks, thereby contributing to a better understanding of the evaluation of potential of occurrence of gas hydrates off SW Taiwan.

\section{GEOLOGICAL SETTING}

The island of Taiwan is located at the junction of the Ryukyu and Luzon Arcs in the northwestern Pacific. Taiwan is mainly comprised of nearly N-S trending fold-and-thrust mountain belts, resulting from oblique collision between the Luzon Arc and the Chinese continental margin in the Late Cenozoic since about 5 Ma (Suppe 1981; Ho 1988; Teng 1990; Biq 1997). Accompanying the rising Taiwan orogen, the western Taiwan foreland basin formed west of the Taiwan orogen (Covey 1984; Yu and Chou 2001; Lin and Watts 2002), extending westward from the Western Foothills and Coastal Plain to the shallow Taiwan Strait from the Pliocene to the present (Fig. 1). Distal to the Taiwan orogen, sediments shed from the Taiwan mountain belts are transported farther southwestward into the northeastern South China Sea, infilling the deep marine basin and forming the shelf-slope topography off the coast of SW Taiwan. The oblique convergence from north to south between the Chinese margin and the Luzon Arc has resulted in an initial collision zone in the offshore region south of Taiwan in the northeastern South China Sea (Lallemand and Tsien 1997; Willett et al. 2003). The initial collision zone, the shelf and slope offshore SW Taiwan in particular, is characterized by westward folds and thrust faults and mud diapiriic intrusions (Sun and Liu 1993; Liu et al. 1997; Chiang et al. 2004). The convergence between the SW Taiwan and the Chinese passive margin has resulted in these contraction structures.

From the viewpoint of sediment source to sink, the shelf-slope region in the northeastern South China Sea off SW Taiwan was considered as an immature under-filled foreland basin (Covey 1984; Yu 2004a). The western Taiwan foreland basin can be extended into offshore southwestern Taiwan dominated by deep marine fine-grained sediment in the early immature stage of foreland basin evolution (Covey 1984). Wu (1993) pointed out that the Pingung foreland basin is comprised of more than $5000 \mathrm{~m}$ of Plio-Pleistocene sediments shed in the southern Taiwan orogen and is dominated by fluvial and shallow marine facies. Sun and Liu (1993) suggested that sediment more than $10000 \mathrm{~m}$ thick derived from southern Taiwan bypassed the 


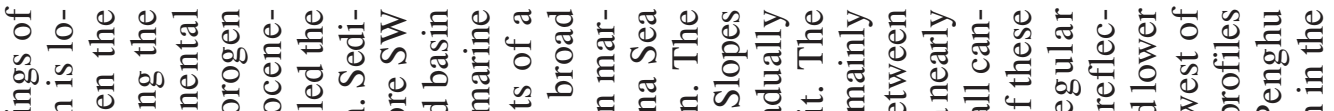

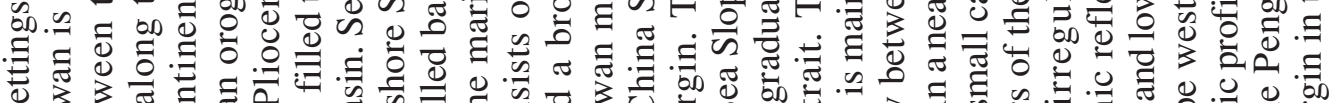

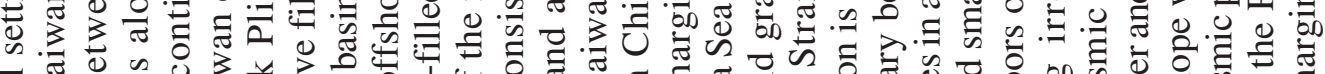

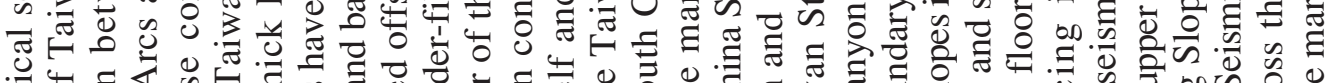
क

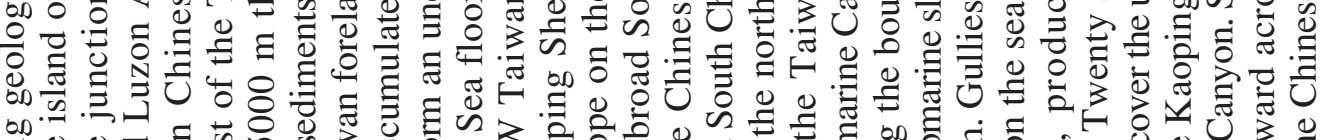

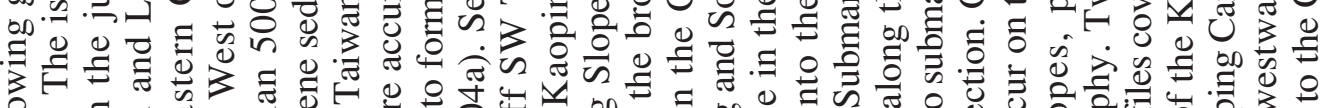

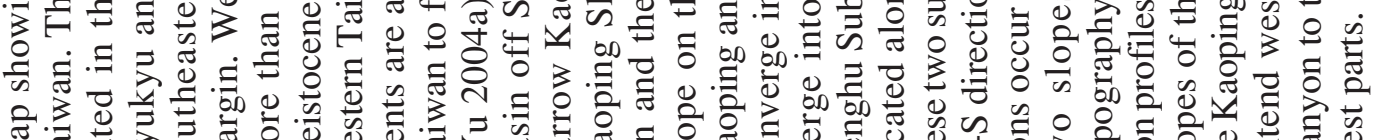

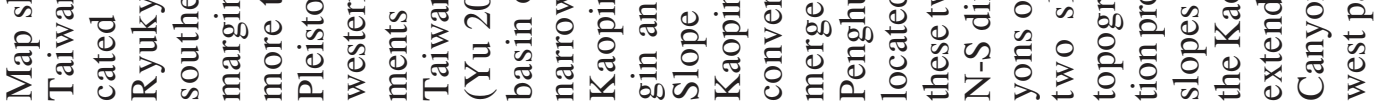

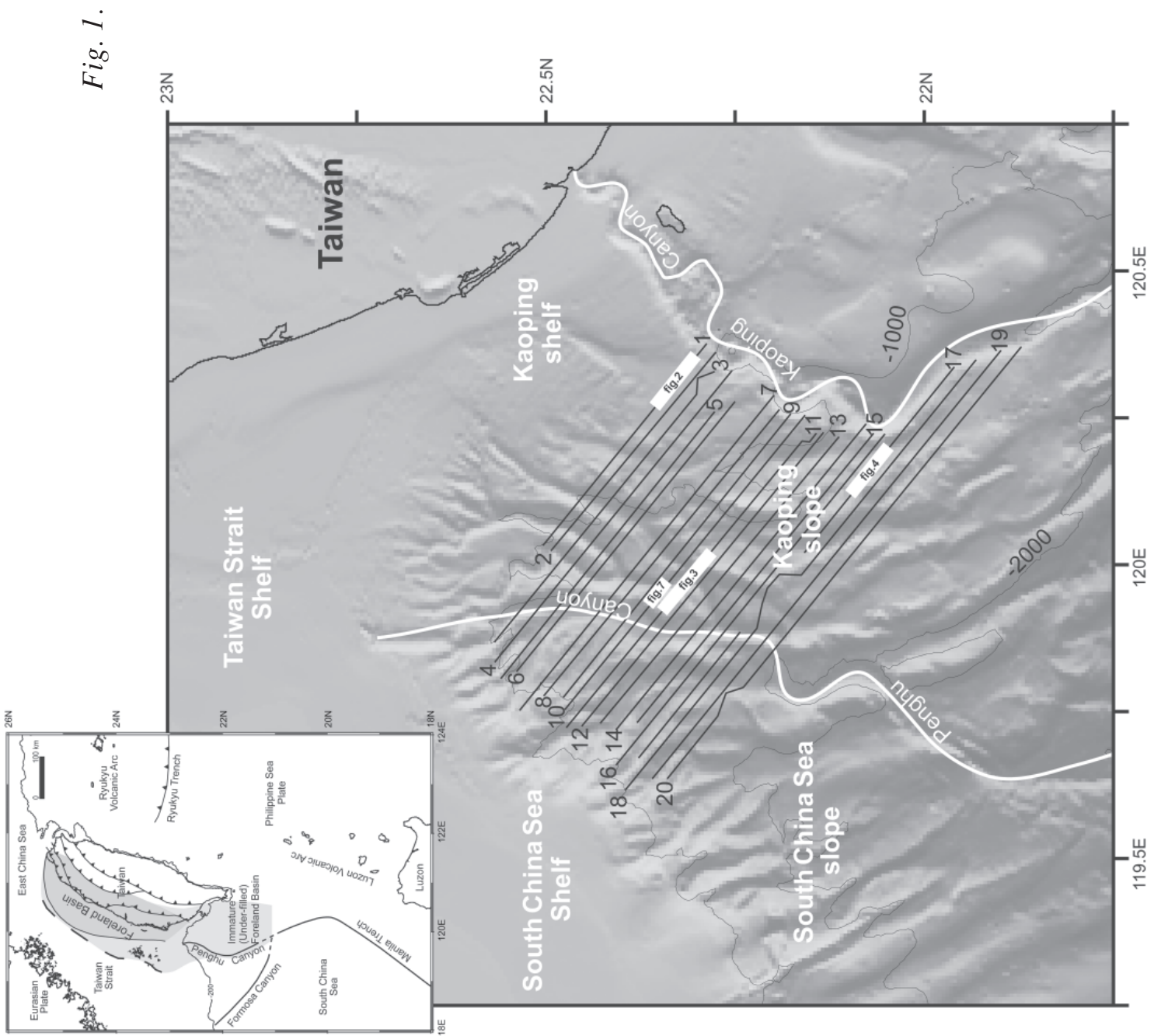


Pingtung Basin and accumulated on the slope off SW Taiwan. Fuh (1997) showed that the Pleistocene (NN19) sediment distribution across the Pingtung Basin and extending seaward into the shelf-slope region off SW Taiwan provided evidence for sediment being shed from Taiwan to the offshore areas of SW Taiwan. Collectively, the Pingtung Basin and the shelfslope region off SW Taiwan can be considered as a wedge-top depozone in terms of a foreland basin system (Chiang et al. 2004).

\section{STUDY AREAS AND DATA}

The offshore areas of SW Taiwan are characterized by a narrow shelf and a relatively broad slope (Fig. 1). The Kaoping Shelf, mainly trending in a NW-SE direction, extends seawards from the coastal plain in SW Taiwan for a distance of about $10 \mathrm{~km}$ and has a relatively shallow sea floor of about $80 \mathrm{~m}$ in depth (Yu and Chiang 1997). The Kaoping Slope extends from the shelf edge southwestwards to a water depth of about $3000 \mathrm{~m}$ and merges westwards into the toe of the South China Sea Slope. There exist two major submarine canyons off the coast of SW Taiwan. The Kaoping Canyon extends immediately from the mouth of the Kaoping River across the shelf to the lower slope and finally merges into the northern Manila Trench (Fig. 1). The other major canyon, the Penghu Canyon, begins at the intersection between two submarine slopes facing each other near the 200 isobath and extends southwards, merging gradually into the northern Manila Trench (Fig. 1). The study areas occupy the upper slope west of the Kaoping Canyon in the Kaoping Slope where they have widespread bottom simulating reflectors, assuming the occurrence of widespread gas hydrates.

Twenty mutli-channel seismic reflection profiles west of the Kaoping Canyon covering the Kaoping Slope in water depths between 300 to $2000 \mathrm{~m}$ were provided solely by C. S. Liu, Institute of Oceanography at the National Taiwan University. Seismic profiles are oriented in a NW-SE direction parallel to shorelines and are spaced in about $20 \mathrm{~km}$, forming a rather dense seismic grid (Fig. 1). Detailed descriptions of seismic data collection and processes are referred to Liu et al. (2006).

\section{INTERPRETATION}

\subsection{Intraslope Basin}

We examined twenty seismic profiles and recognized alternating structural highs and lows formed mainly by mud diapirism as shown in Figs. 2, 3, and 4, respectively. Mud diapiric uplifts can be traced into nearly linear mud diapiric ridges and structural lows can be connected into separated elongated basins. The general trend of these mud diapiric ridges and depressions in between runs in a nearly NE-SW direction (Fig. 5). Our observations are comparable to those structural highs and lows in previous studies (Sun and Liu 1993; Liu et al. 1997; Chiang et al. 2004). Mud diapirism has been active on the shelf and upper to middle slope east of the Kaoping Canyon during Late Pliocene and Pleistocene and mud diapiric intrusions appear as elongated ridges in a NNE-SSW direction (Sun and Liu 1993; Fig. 7; 
Chiu et al. 2006). These mud diapiric ridges are considered as anticlines and can be well correlated with the onshore structures related to mud volcanoes (Yang et al. 2004). The elongated depressions are regarded as synclines receiving muddy sediments transported by paleochannels from the coastal plain of SW Taiwan. In addition to structures caused by mud diapirism, contraction between the Taiwan orogen and the Chinese margin has deformed sediments of

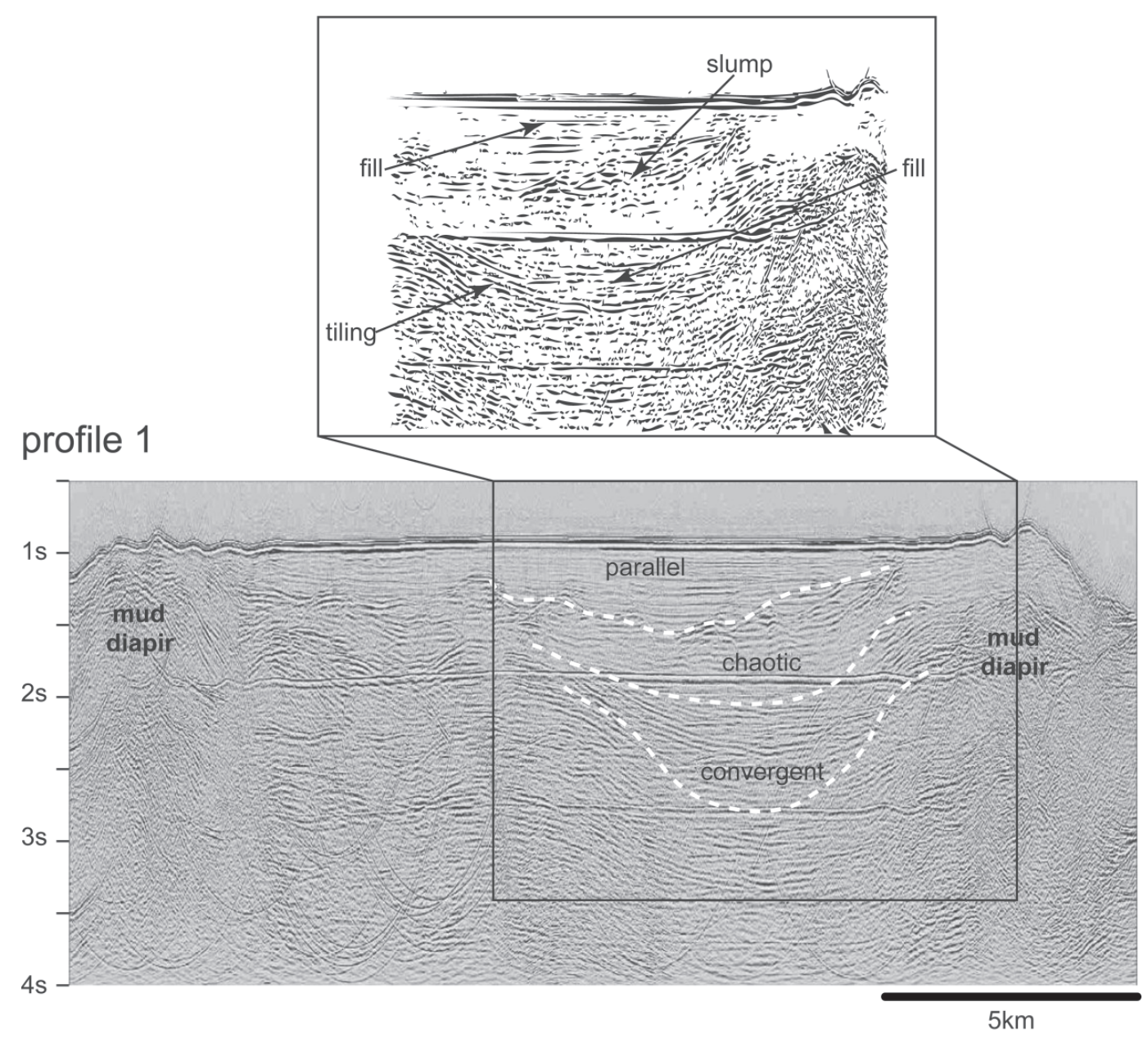

Fig. 2. Seismic profile 1 shows that alternating structural highs and lows are formed by mud diapirim in the upper slope region immediately west of the Kaoping Canyon. It is noted that some mud diapiric intrusions reach to the sea floor and others are below the sea floor. Location of profile 1 is shown in Fig. 1. 


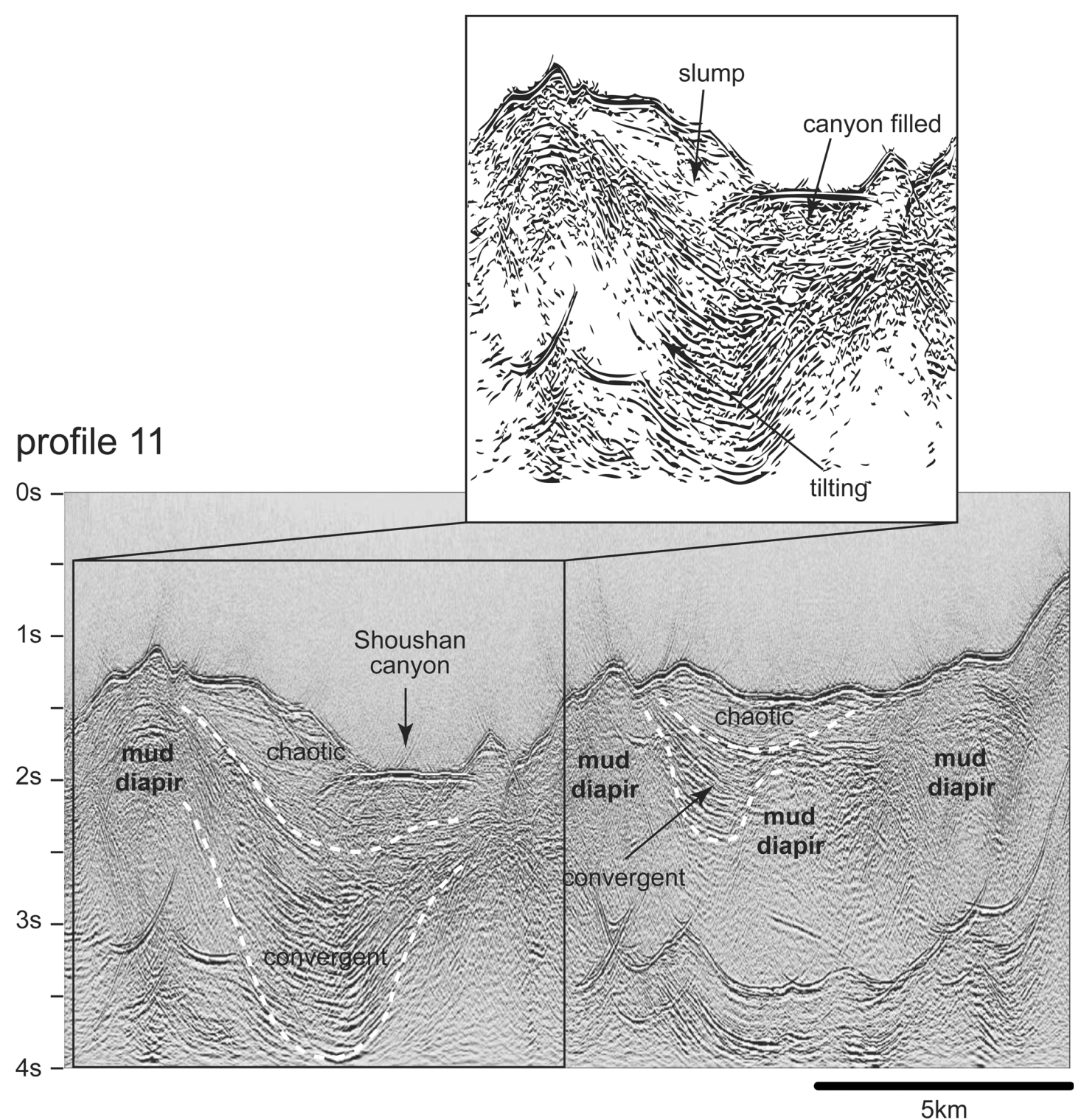

Fig. 3. Seismic profile 11 shows that prominent mud diapiric intrusions move upward and reach the sea floor, forming high-relief topographic ridges. Intraslope basins formed between mud diapiric ridges. Location of profile 11 is shown in Fig. 1. 


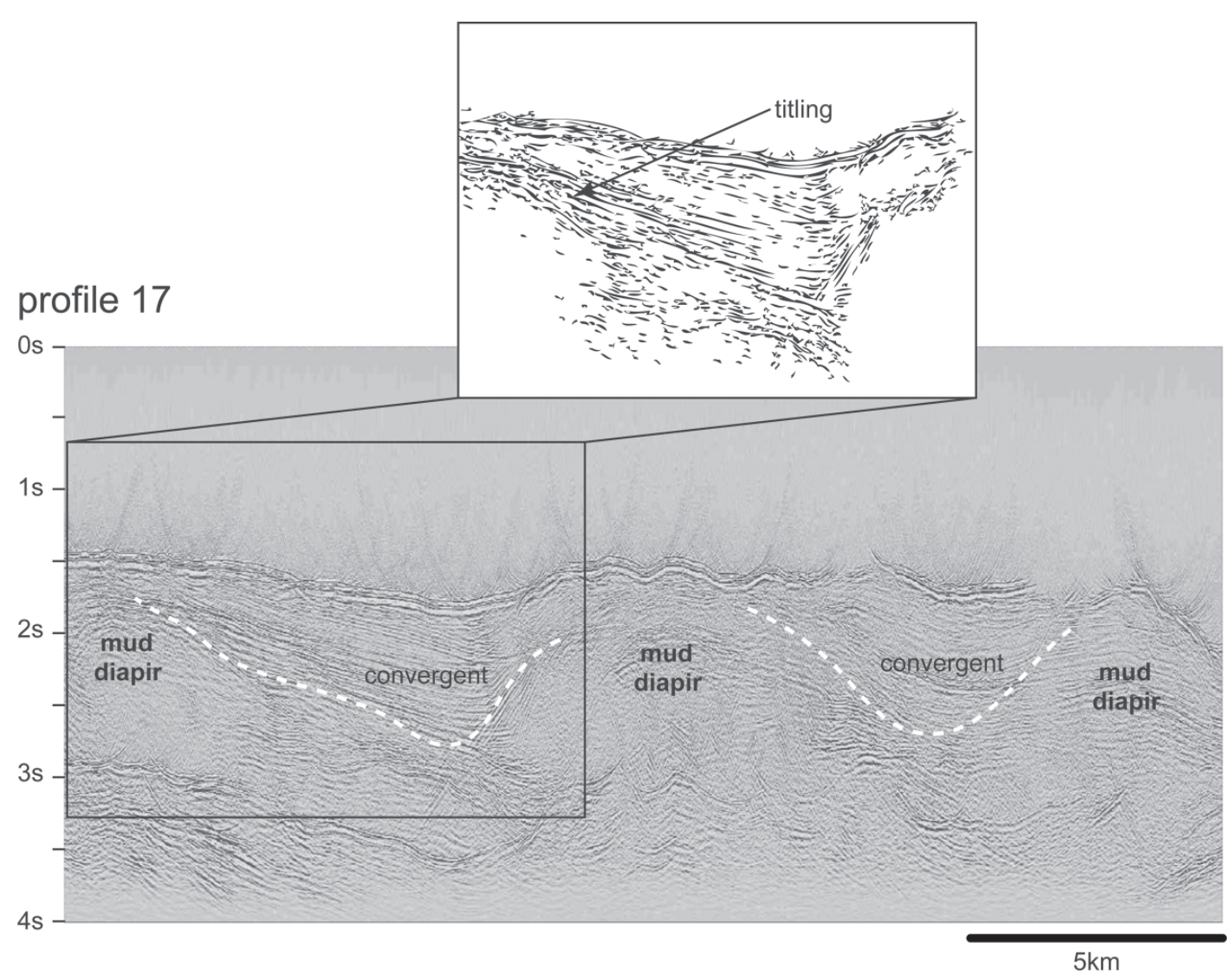

Fig. 4. Seismic profile 17 in the lower slope region shows similar alternating structural highs and lows to those on the profile 11. Location of profile 17 is shown in Fig. 1.

the Kaoping shelf-slope into a series of west-vergent imbricated thrusts and folds (Liu et al. 1997; Chiang et al. 2004). Structural lows between thrust faults and folds are sediment depocenters, forming slope basins (Liu et al. 1997) or piggy-back basins (Chiang et al. 2004) in the Kaoping shelf-slope region.

This paper considers the structural lows between mud diapiric ridges as intraslope basins distinguished from synclines, slope basins and piggy-back basins because we lay emphasis on sedimentary processes rather than structural or tectonic processes to discuss the development of these basins. By definition, intraslope basins are located on the continental slopes where the mud diapirism (salt withdrawal, growth faulting, etc.) produce uplift on adjacent areas, creating a depression (basin) between local highs (Bouma et al. 1978). For example, growth-faulted 


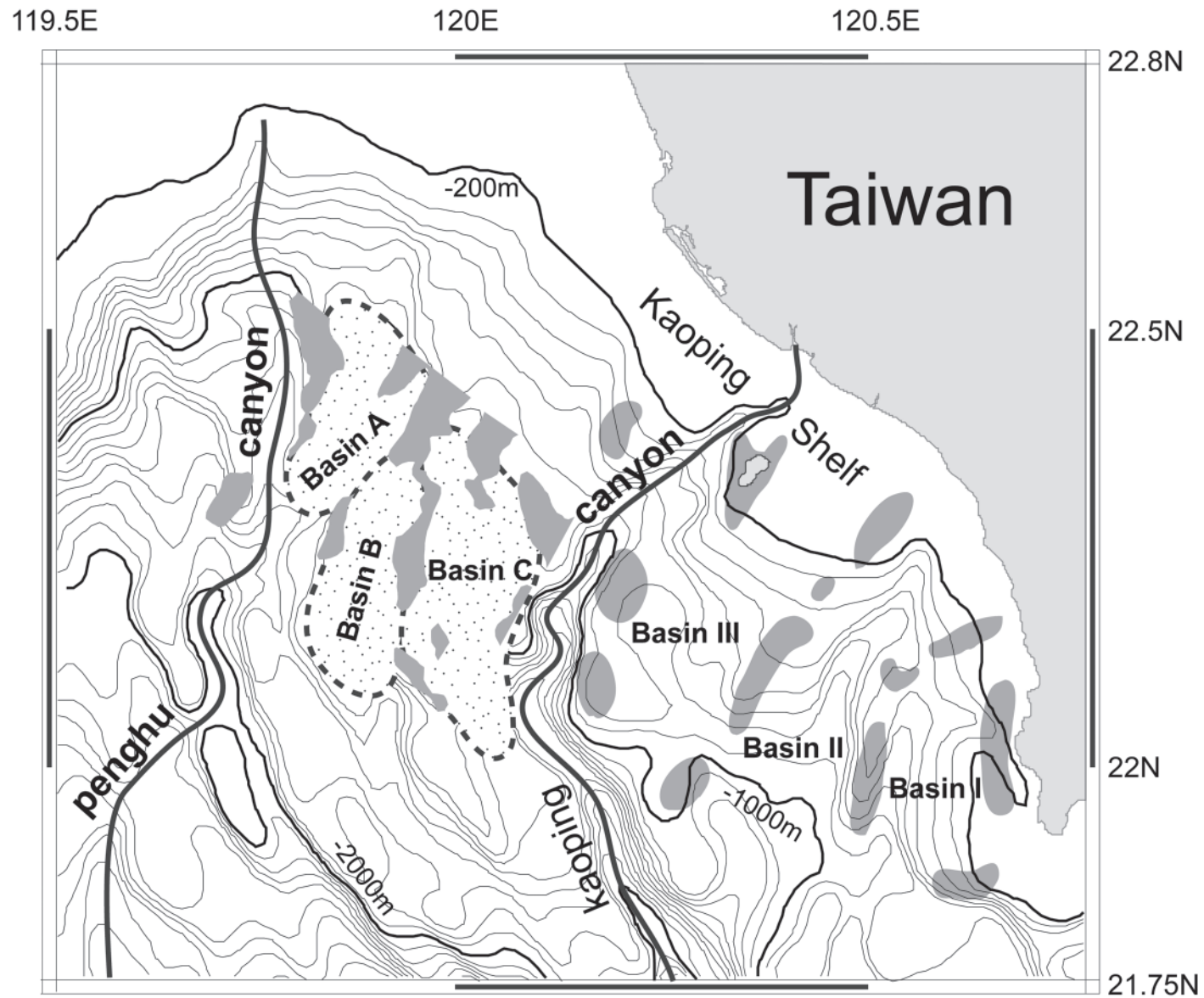

Fig. 5. Three major intraslope basins separated from linear mud diapiric ridges west of the Kaoping Canyon are determined from seismic profiles. They are labeled as basin A, B, and C, respectively. East of the Kaoping Canyon, three intraslope basins named as basin I, II, and III are present (modified from Sun and Liu 1993; Fig. 7). It is noted that intraslope basins west of the Kaoping Canyon are similar to those east of the Kaoping Canyon but are less well confined by mud diapiric ridges.

intraslope basins in the South Texas were discussed by Brown et al. (2004). This definition of an intraslope basin is closely related to the initiation and final in-filled conditions of local depressions in the slope and activities of mud diapirism or salt-withdrawl and the regional slope profile adjustment. 
In plan view there are three major intraslope basins labeled as Basin $\mathrm{A}, \mathrm{B}$, and $\mathrm{C}$, respectively, west of the Kaoping Canyon (Fig. 5). Basin A is bounded by the mud diapirc ridges neighboring the toe of the South China Sea slope and is distal to the sediment source of the Taiwan orogen (in the water depths from 1000 to $1500 \mathrm{~m}$ ). This basin is about $32 \mathrm{~km}$ in length and has a width of about $12 \mathrm{~km}$, showing an elongated shape. Basin B is located southeast of Basin A, separated by a northeast trending mud diapiric ridge and has an average width of about $10 \mathrm{~km}$ and is about $23 \mathrm{~km}$ long, narrowing towards upper slope. Basin $\mathrm{C}$ lies east of the Basin B and has a basin axis trending in a more or less N-S direction. It is about $42 \mathrm{~km}$ long and about $16 \mathrm{~km}$ in average, displaying an elongated shape with irregular sides along the bounding ridges. These three basins are elongated mainly because they were formed by mud diapirism in contrast to circular or semi-circular patterns usually induced by salt-withdrawal (Prather 2000). It is noted that the edges along mud ridges west of the Kaoping canyon are more irregular than that of mud ridges east of the canyon and probably due to this study's dense seismic grid and the ability to produce higher resolution.

\subsection{Seismic Facies Analysis}

Seismic facies analysis has been used since the late 1970s and well applied to interpret sedimentary processes and depositional environments in passive continental margins (Mitchum et al. 1977; Sangree and Widmier 1977). Seismic facies analysis was also used to study intraslope basins, relating seismic facies, to lithology, depositional processes and basin evolution (e.g., Behrens 1985; Pratson and Ryan 1994; Pratther et al. 1998; Prather 2000; Weimer et al. 1998; Crews et al. 2000; Brown et al. 2004). This paper modifies and applies seismic facies analysis of intralope basins (Prather et al. 1998; Weimer et al. 1998) to intraslope basins in the Kaoping Slope. Using criterion of bounding surface configuration, external geometry, seismic reflection amplitude and continuity, we examined twenty seismic profiles crossing the Kaoping Slope west of the Kaoping Canyon (Fig. 1) and determined three primary types of seismic facies : (1) convergent-baselapping, (2) chaotic and (3) parallel and draping (Fig. 6). However, other less common seismic facies such as the transparent facies also observed is so rare that it is not significantly related to the sedimentary processes. Thus, it is not discussed further in this study.

The convergent-baselapping seismic facies is characterized by internal reflectors converging towards the flanks of the basin (Fig. 6). Internal reflection continuity varies from continuous to moderately discontinuity and the amplitude strength ranges from strong to moderately weak. Internal reflectors terminate against the flanks of basin show both onlap and downlap that are collectively called baselap because the accurate discrimination between them is difficult in the complex intraslope basin. Activities of mud diapirism in the Kaoping Slope are multiple and episodic with various uplifting rates along the flanks of the mud ridges (Sun and Liu 1993). Equal rates of uplifting of both flanks of the mud ridges resulted in a symmetrical basin profile (Fig. 6). Later, sediments accumulated on the bottom of the intraslope basin forming symmetrical convergent-baselapping seismic facies. Unequal rates of uplifting of both flanks of the mud ridges resulted in an asymmetrical or wedge-shaped trough (Fig. 6). After sediment filled the bottom of the intraslope basin, the basin fills display convergent-baselapping seismic facies. The chaotic seismic facies is characterized by discontinuous and wavy reflec- 

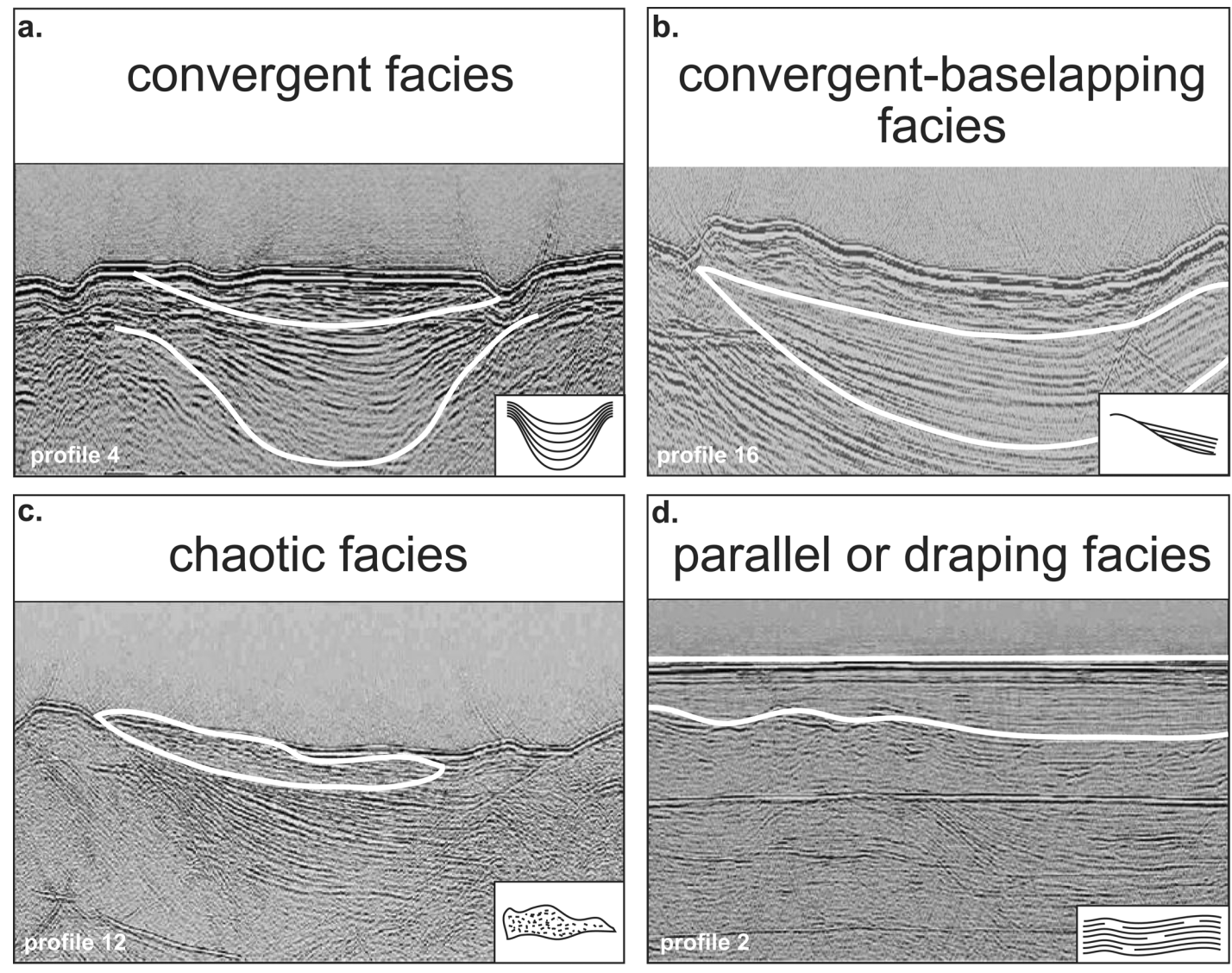

Fig. 6. Three major types of seismic facies determined from seismic profiles covering the slope areas west of the Kaoping Canyon. They are convergent, chaotic, parallel or draping facies.

tors with no definite patterns (Fig. 6). Slumping and sliding related to mass wasting are common features in the active margin slopes, including the Kaoping Slope (Liu et al. 1997; Yu 2004b). Chaotic facies recognized in the intraslopes basins of the Kaoping Slope are most likely the result from processes of slumping and sliding. Seismic profile 10 shows that truncated reflections appear at the east flank of the mud diapir could be a result from slumping due to an oversteeping of the east flank (Fig. 7). Slumped materials are transported down-slope and are deposited at the edge of the adjacent intraslope basin (Fig. 7). Reflection amplitude strength ranges considerably from strong to relatively weak. Chaotic facies may represent a variable energy regime including turbidity currents in the slope environments. The parallel and draping 
facies is characterized by highly continuous and parallel reflections draping on the underlying bounding surfaces either in a confined trough or unconfined basins (Fig. 6). Mass wasting and slope retreat may take place as the slope profile grades to shallower angles following episodes of rapid mud diapirism and syn-deposition in the intraslope basins. Finer grained sediments are prevalent and remain in suspension and are then transported downslope, resulting in parallel and draping facies at the top of intraslope basins in the upper slope region. These sheet drape sediments are an indication of hemi-pelagic and low energy sediments draping over preexisting topography.

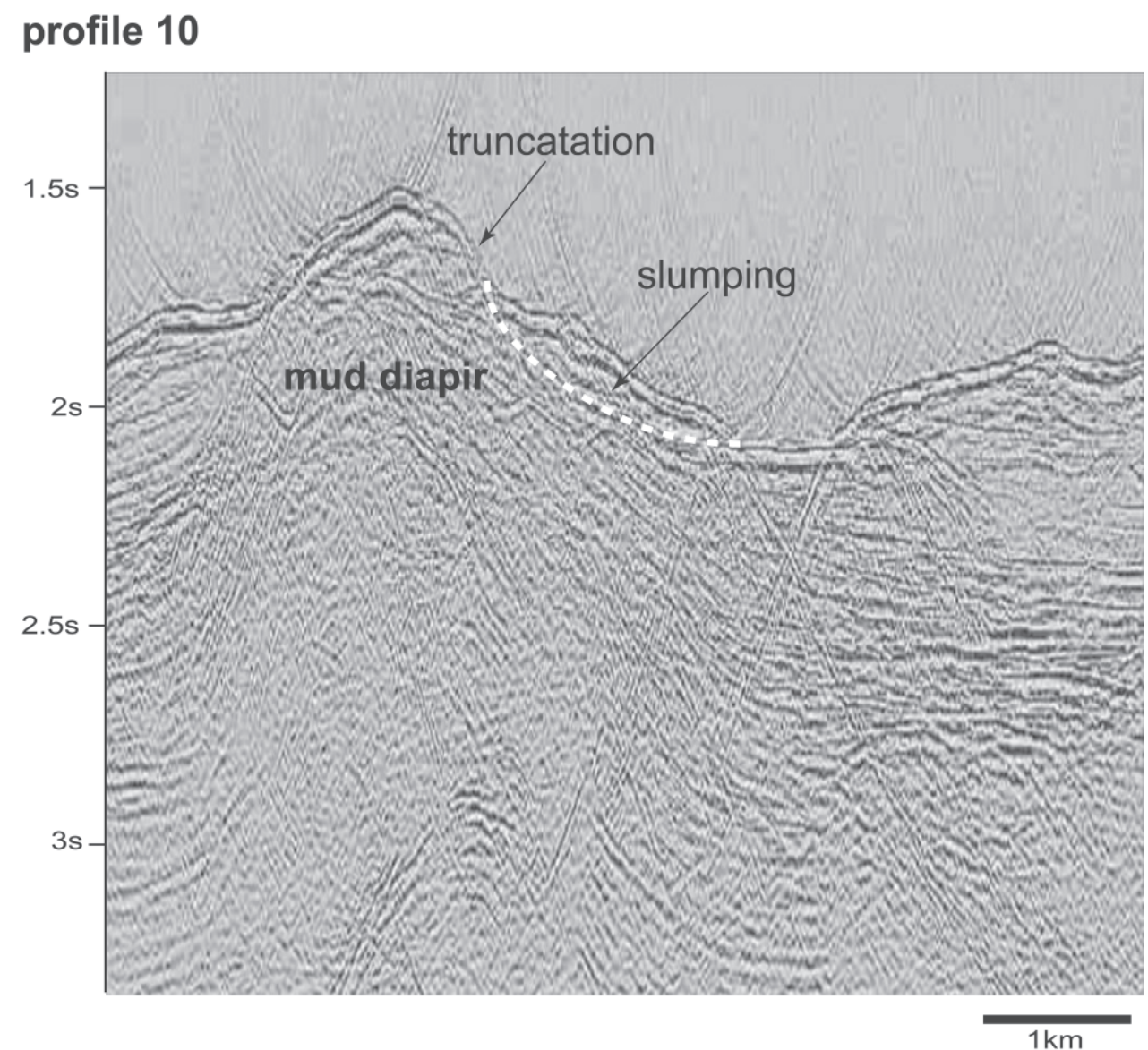

Fig. 7. Seismic profile 10 shows that truncated reflections appear at the east flank of the mud diapir could be the result from slumping due to an oversteeping of the east flank Slumped materials are transported down-slope and are accumulated at the edge of the adjacent intraslope basin. 
The occurrence of convergent-baselapping faices is usually confined in the basal parts of intraslope basins. It is, in turn, succeeded by chaotic facies and then overlain by parallel and draping facies, forming a distinct upward change in seismic facies (Fig. 2). It is noted that the basal convergent-baselapping facies is the most common and the parallel and draping facies is restricted to slope areas shallower than $1000 \mathrm{~m}$ in water depth (Fig. 8). Draping facies range in thickness from 15 to $300 \mathrm{~m}$ and are fairly common in upper-slope intraslope basins, particularly in shallow basin-fill successions. The vertical and lateral distributions of seismic facies are interpreted in terms of sedimentary processes of filling the intraslope basins in the Kaoping Slope. A simplified schematic sedimentation model of a downslope fill and spill depositional style for development of the intraslope basins in the Kaoping Slope is presented as follows (Fig. 9).

\subsection{Sedimentary Processes}

The foreland basin in SW Taiwan progressively migrated southwestward during Late Pliocene and Quaternary (Chen et al. 2001; Hong 1997) and resulted in a continuous supply of sediment to the offshore areas of SW Taiwan. Incision of valleys into the SW Taiwan coastal plains (Sun and Liu 1993) and mass wasting on the shelf edge and upper slope (Chuang and Yu 2002) provided sediments to development along the Kaoping Slope. During evolution of the Kaoping Slope, strata of the Kaoping Slope have been deformed by mud diapirism, resulting in depressions confined by mud diapiric ridges along the slope. As mentioned before, structural deformation in SW Taiwan has propagated southwestward and hence resulted in the formation of intraslope basins with progressive decreases in basin size and accommodation space seaward (Fig. 9a). Continued sediment supply accompanied the formation of intraslope basins would infill the lowest parts of depressions depending on competing rates between sediment supply and basin subsidence. It is inferred that intraslope basins located along the upper slope proximal to sediment source would be filled partially by sediments and the depressions situated in the lower slope would be starved with little sediment infilling mainly due to distal to sediment sources. Sediments filled the confined accommodation space of the basin bottom when flanks of intraslope basins maintain relatively stable, resulting in onlap seismic facies with flat and parallel reflectors terminating against basin flanks. However, the mud ridges formed in the early stage tend to move upward and would drag the ends of reflectors upwards and resulted in convergent-baselapping seismic facies commonly observed on our seismic profiles. Sediments have been continuously transported downslope to a lower slope distal to the sediment sources. Progressive sediment filling up and bypassing intraslope basins took place (Fig. 9b). Sediments from the shelf and upper slope continuously were transported downslope and filled up the intraslope basins at the upper slope and parts of sediment bypassed the infilled basin and began to fill the space of the basin bottom. Subsequent to fillingup the confined space of the bottom of intraslope basins, sediments transported downslope tended to accumulate on top of the convergent-baselapping facies and resulted in the chaotic seismic facies commonly associated with slumping and sliding.

After intraslope basins filled by sediments characteristic of the basal convergent-facies succeeded by chaotic facies, active uplifting of ridge flanks would continue and create addi- 

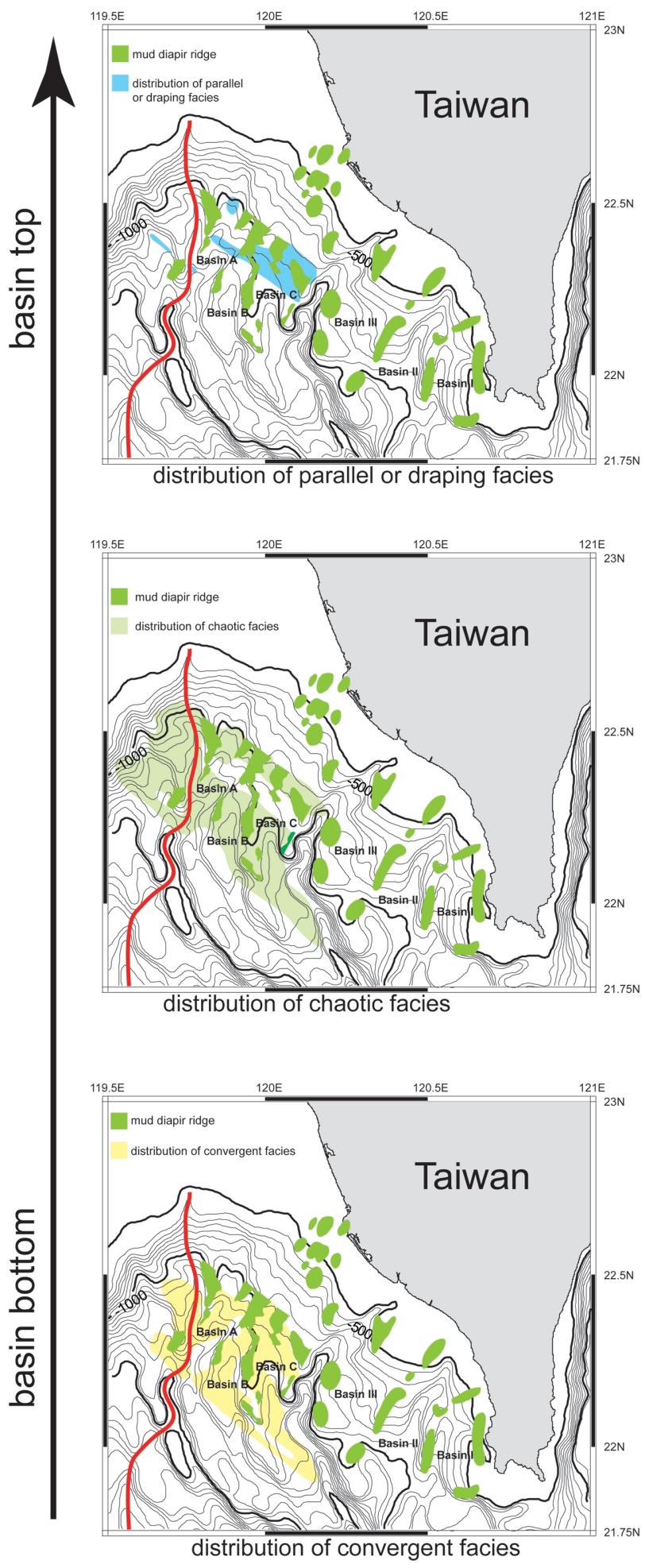

Fig. 8. Lateral distribution of three major types of seismic facies. The basal convergent facies is the most common one and is distributed from upper slope to lower slope areas and the chaotic facies is the less common one. The parallel and draping facies is the least common one and is restricted to the upper slope region. 


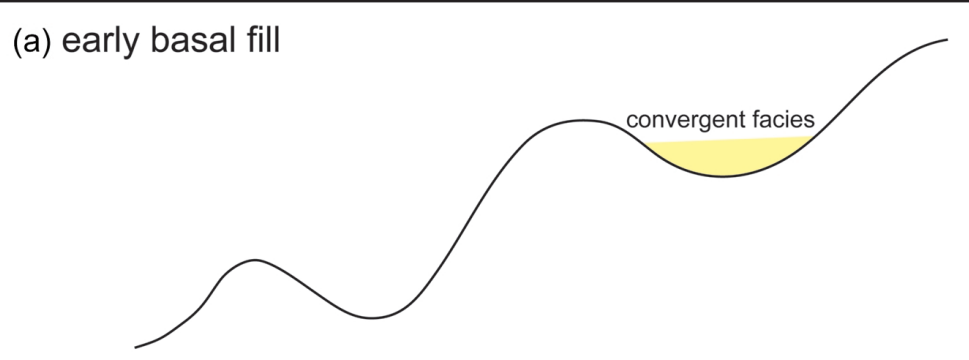

(b) fill and bypass

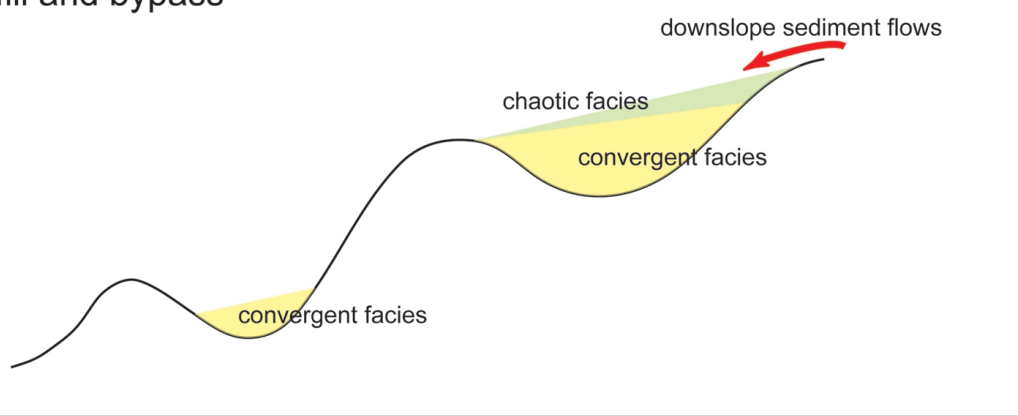

(c) slope progradation and flank fill

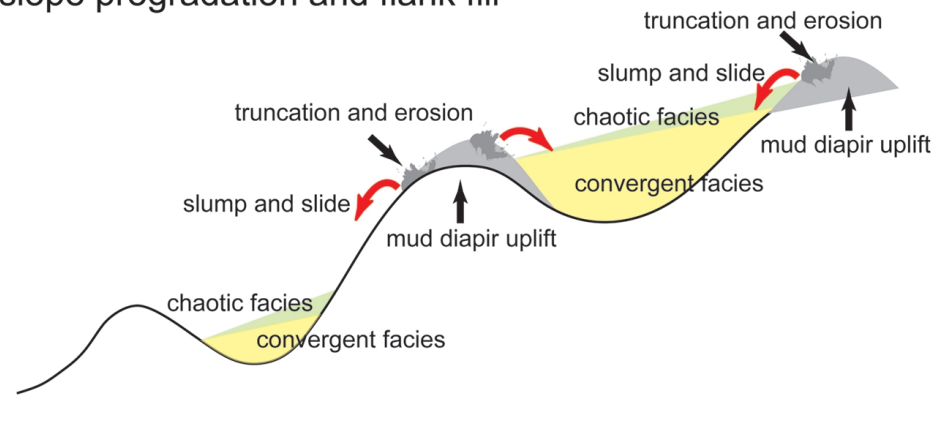

(d) fill and spill

parallel facies

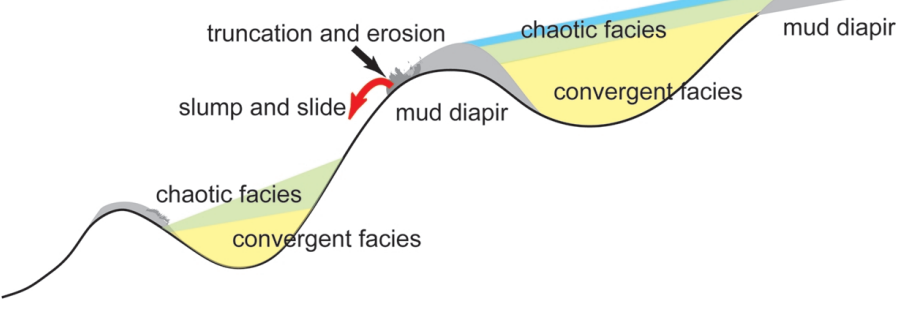

Fig. 9. A simplified schematic sedimentation model of downslope fill and spill depositional style for development of the intraslope basins in the Kaoping Slope. 
tional accommodation space available for future sediment-filling. Slope progradation and flank fill would likely proceed (Fig. 9c). The uppermost parts of mud ridges are likely to become unstable and eroded away probably because of over-steepness of the ridge flanks. Slumping and sliding would occur at the flanks of the ridge tops, shedding eroded sediments to intraslope basins and forming chaotic facies. Intraslope basins in the lower slope tend to receive sediments from nearby uplifted mud ridges, forming chaotic facies overlying older basal convergent facies (Fig. 9c). Mass-wasting and downslope gravity flows were less active at the late depositional stage probably due to slope readjustment to subdued profile in the upper slope. Fine-grained sediments derived from the seaward prograding slope were transported mainly in suspension and were deposited to form parallel and draping facies, overlying the chaotic facies in the intraslope basins. The intraslope basins in the lower slope distal to sediment source in the upper slope received sediment in suspension less than that from the local sediment source from nearby uplifted ridge flanks, resulting in an increase in thickness of chaotic facies without the presence of draping facies (Fig. 9d).

Creation of confined accommodation space and subsequent sediment infilling occur repetitively dominated in the early stage of intraslope basin development. In the late stage sediments have been transported to lower slope distal to the sediment sources, progressively filling and spilling intraslope basins in a generally southwestward direction.

\section{DISCUSSION}

Mud diapiric activities in the Kaoping Shelf and Slope have been recognized (e.g., Chang 1993; Sun and Liu 1993; Huang 1995; Yu and Lu 1995; Chow et al. 2000; Chiu et al. 2006). These previous studies paid attention to descriptions of morphology of mud diapiric intrusions and related structures and discussions of possible origin. The formation of intraslope basins associated with mud diapirism was little discussed. As a mater of fact, the origin of mud diapirs remains controversial. For example, mud diapirism may be caused by expulsion of fluids (Westbrook and Smith 1983), sediment overburden (Limonov et al. 1996), regional plate motion (Sumner and Westbrook 2001), rapid sedimentation and subsequent tectonic compression (Aisan et al. 2001) and compressional tectonic activity (Yassir 2003). The exact mechanism of formation of intraslope basins and accompanied mud diapirism is beyond comprehensive analysis. Hence, the interpretations of sedimentary processes for intraslope basins in the Kaoping Slope should be cautioned against without considering the complex history of uplifts of the mud ridges and subsidence of the nearby basins.

\section{SUMMARY AND CONCLUSIONS}

Interactions between regional contraction tectonics, local mud diapirism and foreland sedimentation resulted in the formation of intraslope basins, mainly controlled by mud diapirism and filled by sediment derived from the Taiwan orogen, characterized the sea floor morphology and tectono/sedimentary features of the Kaoping Slope. Three major intraslope basins trend mainly northeast, separated by linear mud diapiric ridges and are about $40 \mathrm{~km}$ in length 
and around $12 \mathrm{~km}$ in width. Emplacement of orogenic sediment of Taiwan occurred as the Taiwan orogen migrated westward towards the stable Chinese margin and transported syntectonic sediment to the deep marine under-filled foreland basin offshore SW Taiwan during Late Pliocene and Quaternary. Subsequently, sediments both from the uprising Taiwan orogen and erosion of locally flanking structural highs were progressively in-filled and spilled over these intraslope basins in a generally southward direction. The convergent-baselapping faices usually occurs in the basal parts of intraslope basins. It is, in turn, succeeded by chaotic facies and then overlain by parallel and draping facies, forming a distinct upward change in seismic facies. The basal convergent-baselapping facies is the most common and the parallel and draping facies are restricted to slope areas shallower than $1000 \mathrm{~m}$ in water depth. The vertical and lateral distributions of seismic facies are interpreted in terms of sedimentary processes of filling the intraslope basins in the Kaoping Slope. The early confined basal basin-fill stage characterized by basal convergent and overlying chaotic facies and the late unconfined slope progradation and spill over deposition represented by parallel and draping facies. The conclusions are preliminary mainly due to concept-oriented nature.

Acknowledgements We thank the Central Geological Survey of Taiwan for permission to publish investigation results. Prof. C. S. Liu kindly provided multi-channel seismic profiles for this study. Comments from Louis Teng and Dennis Brown greatly improved this manuscript.

\section{REFERENCES}

Aisan, A., E. H. Guevara, R. C. Smyth, J. A. Rancy, J. C. Gibeau, A. G. Warne, and W. A. White, 2001: Mud volcanoes of the Orinoco Delta, Eastern Venezuela. Geomorphology, 41, 323-336.

Behrens, E. W., 1985: Unifite muds in intraslope basins, Northwest Gulf of Mexico. Geo-Mar. Lett., 4, 227-233.

Biq, C., 1997: Taiwan. In: Moore, E. M, and R. W. Fairbridge (Eds), Encyclopedia of European and Asian geology, Chapman \& Hall, London, 711-717.

Bouma, A. H., L. B. Smith, B. R. Sidner, and T. R. McKee, 1978: Intraslope basin in northwest Gulf of Mexico. In: Bouma, A. H. et al. (Eds), Framework, Facies and Oil-Trapping Characteristics of the Upper Continental Margin, AAPG Studies in Geology, 7, 289-302.

Brown, Jr. L. F., R. C. Loucks, R. H. Trevino, and U. Hammes, 2004: Understanding growthfaulted, intraslope subbasins by applying sequence-stratigraphic principles: examples from the south Texas Oligocene Frio Formation. AAPG Bull., 88, 1501-1522.

Chang, C. W., 1993: Mud diapirs of the offshore southwestern Taiwan. Master Thesis, Natl. Taiwan Univ., Taiwan, 62 pp.

Chen, W. S., K. D. Ridgway, C. S. Horng, Y. G. Chen, K. S. Shea, and M. G. Yeh, 2001: Stratigraphic architecture, magnetostratigraphy, and incised-valley system of the Plioccene-Pleistocene collisional marine foreland basin of Taiwan. Bull. Geol. Soc. Am., 113, 1249-1271. 
Chi, W. C., D. L. Reed, C. S. Liu, and N. Lundberg, 1998: Distribution of the bottom simulating reflector in the offshore Taiwan collision zone. Terr. Atmos. Ocean. Sci., 9, 779-793.

Chiang, C. S., H. S. Yu, and Y. W. Chou, 2004: Characteristics of the wedge-top depozone of the southern Taiwan foreland basin system. Basin Res., 16, 65-78.

Chiu, J. K., W. H. Tseng, and C. S. Liu, 2006: Distribution of gassy sediments and mud volcanoes offshore southwestern Taiwan. Terr. Atmos. Ocean. Sci., 17, 703-722.

Chow, J., J. S. Lee, C. S. Liu, R. Sun, and N. Lundberg, 2000: Characteristics of the bottom simulating reflectors near mud diapirs: offshore southwestern Taiwan. Geo-Mar. Lett., 20, 3-9.

Chuang, C. Y., and H. S. Yu, 2002: Morphology and canyon forming processes of upper reach of the Penghu submarine canyon off southwestern Taiwan. Terr. Atmos. Ocean. Sci., 13, 91-108.

Covey, M., 1984: Lithofacies analysis and basin reconstruction, Plio-Pleistocene western Taiwan foredeep. Petrol. Geol. Taiwan, 20, 53-83.

Crews, J. R., P. Weimer, A. J. Pulham, and A. S. Waterman, 2000: Integrated approach to condensed section identification in intralope basins, Pliocene-Pleistocene, northern Gulf of Mexico. AAPG Bull., 84, 1519-1536.

Fuh, S. C., 1997: Structural evolution of the oblique arc-continent collision onland and offshore southern Taiwan. Ph. D. Thesis, Natl. Taiwan Univ., Taiwan, 166 pp.

Ho, C. S., 1988: An introduction to the geology of Taiwan: explanatory text for the geological map of Taiwan, Minist. Econ. Aff., Taiwan, 192 pp.

Hong, E., 1997: Evolution of Pliocene to Pleistocene sedimentary environments in an arccontinent collision zone: evidence form the analysis of lithofacies and ichnofacies in the southwestern foothills of Taiwan. J. Asian Earth-Sci., 15, 381-392.

Huang, W. L., 1995: Mud diapirs of the offshore southwestern Taiwan. Master Thesis, Natl. Taiwan Univ., Taiwan, 63 pp.

Lallemand, S. E., and H. H. Tsien, 1997: An introduction to active collision in Taiwan. Tectonophysics, 274, 1-3.

Limonov, A. F., J. M. Woodside, M. B. Cita, and M. K. Ivanov, 1996: The Mediterranean Ridge and related mud diapirism: a background. Mar. Geol., 132, 7-19.

Lin, A. T., and A. B. Watts, 2002: Origin of the West Taiwan Basin by orogenic loading and flexure of a rifted continental margin. J. Geophys. Res., 107, 1029-1048.

Liu, C. S., Y. L. Huang, and L. S. Teng, 1997: Structural features off southwestern Taiwan. Mar. Geol., 137, 305-319.

Liu, C. S., P. Schnürle, Y. Wang, S. H. Chung, S. C. Chen, and T. H. Hsiuan, 2006: Distribution and characters of gas hydrate offshore of southwestern Taiwan. Terr. Atmos. Ocean. Sci., 17, 615-644.

Mitchum, R. M., P. R. Vail, and J. b. Sangree, 1977: Seismic stratigraphy and global changes of sea level, part 6: stratigraphic interpretation of seismic reflection patterns in depositional sequences. In: Payton, C. E. (Ed.), Seismic Stratigraphy- Applications to Hydrocarbon Exploration, AAPG Mem., 26, 117-133.

Prather, B. B., J. R. Booth, G. S. Steffens, and P. A. Craig, 1998: Classification, lithologic calibration, and stratigraphic successions of seismic facies of intraslope basins, deepwater Gulf of Mexico. AAPG Bull., 82, 701-728. 
Prather, B. E., 2000: Calibration and visualization of depositional process models for abovegrade slopes: a case study from the Gulf of Mexico. Mar. Petrol. Geol., 17, 619-638.

Pratson, L. F., and W. B. F. Ryan, 1994: Pliocene to recent infilling and subsidence of intraslope basins offshore Louisiana. AAPG Bull., 78, 1483-1506.

Sangree, H. B., and J. M. Widmier, 1977: Seismic interpretation of clastic depositional facies. In: Payton, C. E. (Ed.), Seismic Stratigraphy- Applications to Hydrocarbon Exploration, AAPG Mem., 26, 165-184.

Sumner, R. H., and G. K. Westbrook, 2001: Mud diapirism in the front of the Barbados accretionary wedge: the influence of fracture zones and North America-South America plate motions. Mar. Petrol. Geol., 8, 591-613.

Sun, S. C., and C. S. Liu, 1993: Mud diapirs and submarine channel deposits in offshore Kaohsiung-Hengchun, southwest Taiwan. Petrol. Geol. Taiwan, 28, 1-14.

Suppe, J., 1981: Mechanics of mountain building and metamorphism in Taiwan. Mem. Geol. Soc. China, 4, 67-89.

Teng, L. S., 1990: Geotectonic evolution of Late Cenozoic arc-continent collision in Taiwan. Tectonophysics, 183, 57-76.

Weimer, P., P. Varnai, and F. M. Budhijano, 1998: Sequence stratigraphy of Pliocene and Pleistocene turbidite systems, northern Green Canyon and Ewing Bank (offshore Louisiana), northern Gulf of Mexico. AAPG Bull., 82, 918-960.

Westbrook, G. K., and M. J. Smith, 1983: Long decollements and mud volcanoes: evidence from the Barbados Ridge Complex for the role of high pore-pressure in the development of an accretionary complex. Geology, 11, 279-283.

Willett, S. D., D. Fisher, C. Fuller, E. C. Yeh, and C. Y. Lu, 2003: Erosion rates and orogenwedge kinematics in Taiwan inferred from fission-track thermochronometry. Geology, 31, 945-948.

Wu, L. C., 1993: Sedimentary basin successions of the upper Neogene and Quaternary Series in the Chishan area, southern Taiwan and its tectonic evolution. Ph. D. Thesis, Natl. Taiwan Univ., Taiwan, 212 pp.

Yang, T. F., G. H. Yeh, C. C. Fu, C. C. Wang, T. F. Lan, H. F. Lee, C. H. Chen, V. Walia, and Q. C. Sung, 2004: Composition and exhalation flux of gases from mud volcanoes in Taiwan. Environ. Geol., 46, 1003-1011.

Yassir, N., 2003: The role of shear stress in mobilizing deep-seated mud volcanoes: geologi$\mathrm{cal}$ and geomechanical evidence from Trinidad and Taiwan. Geol. Soc. Am. Spec. Publ., 216, $461-474$.

Yu, H. S., and J. C. Lu, 1995: Development of the shale diapir-controlled Fangliao Canyon on the continental slope off southwestern Taiwan. J. SE Asian Earth-Sci., 11, 265-276.

Yu, H. S., and C. S. Chiang, 1997: Kaoping Shelf: Morphology and tectonic significance. $J$. SE Asian Earth-Sci., 15, 9-18.

Yu, H. S., and Y. W. Chou, 2001: Characteristics and development of the flexural forebulge and basal unconformity of Western Taiwan Foreland Basin. Tectonophysics, 333, 277291.

Yu, H. S., 2004a: An under-filled foreland basin in the northern South China Sea off southwest Taiwan: incipient collision and foreland sedimentation. Geophys. Monogr. Series, 149, 159-173. 
Yu, H. S., 2004b: Nature and distribution of the deformation front in the Luzon Arc-Chinese continental margin collision zone at Taiwan. Mar. Geophys. Res., 25, 109-122.

Yu, H. S., and Z. Y. Huang, 2006: Intraslope basin, seismic facies and sedimentary processes in the Kaoping slope, offshore southwestern Taiwan. Terr. Atmos. Ocean. Sci., 17, 659-677. 